\title{
Formulation and optimisation of raft-forming chewable tablets containing $\mathrm{H}_{2}$ antagonist
}

\author{
Shailesh T Prajapati, Anant P Mehta, Ishan P Modhia, Chhagan N Patel ${ }^{1}$ \\ Departments of Pharmaceutics and Pharmaceutical Technology, ${ }^{\top}$ Pharmaceutical Chemistry, Shri Sarvajanik Pharmacy College, \\ Gujarat, India
}

\begin{abstract}
Purpose: The purpose of this research work was to formulate raft-forming chewable tablets of $\mathrm{H}_{2}$ antagonist (Famotidine) using a raft-forming agent along with an antacid- and gas-generating agent. Materials and Methods: Tablets were prepared by wet granulation and evaluated for raft strength, acid neutralisation capacity, weight variation, \% drug content, thickness, hardness, friability and in vitro drug release. Various raft-forming agents were used in preliminary screening. A $2^{3}$ full-factorial design was used in the present study for optimisation. The amount of sodium alginate, amount of calcium carbonate and amount sodium bicarbonate were selected as independent variables. Raft strength, acid neutralisation capacity and drug release at 30 min were selected as responses. Results: Tablets containing sodium alginate were having maximum raft strength as compared with other raft-forming agents. Acid neutralisation capacity and in vitro drug release of all factorial batches were found to be satisfactory. The $F_{5}$ batch was optimised based on maximum raft strength and good acid neutralisation capacity. Drug-excipient compatibility study showed no interaction between the drug and excipients. Stability study of the optimised formulation showed that the tablets were stable at accelerated environmental conditions. Conclusion: It was concluded that raft-forming chewable tablets prepared using an optimum amount of sodium alginate, calcium carbonate and sodium bicarbonate could be an efficient dosage form in the treatment of gastro oesophageal reflux disease.
\end{abstract}

Key words: Acid neutralisation capacity, famotidine, raft-forming agent, raft strength, sodium alginate, texture analyzer

\section{INTRODUCTION}

Gastro-oesophageal reflux disease (GERD) is an ongoing condition in which the contents of the stomach come back into the oesophagus (the tube that carries food from the mouth to the stomach). Doctors call this "acid reflux." GERD often causes heartburn, a burning feeling in the chest and throat. Heartburn may happen many times a week, especially after eating or at night. GERD can also cause cough or have asthma symptoms. It can also make your voice sound hoarse and raspy. Various treatment options available for GERD are taking medicines like antacids,

\section{Address for correspondence:}

Dr. Shailesh T Prajapati,

Shri Sarvajanik Pharmacy College, Department of Pharmaceutics and Pharmaceutical Technology, Near Arvind Baug,

Mehsana - 384 001, Gujarat, India.

E-mail: stprajapati@hotmail.com

\begin{tabular}{|l|l|}
\hline \multicolumn{2}{|c|}{ Access this article online } \\
\hline Quick Response Code: & Website: \\
\hline & www.jpionline.org \\
\cline { 2 - 2 } & DOI: \\
\hline
\end{tabular}

$\mathrm{H}_{2}$ antagonist, proton pump inhibitor, etc.; surgery to strengthen the barrier between the stomach and the oesophagus may be a treatment option for acid reflux and endoscopic treatments help strengthen the muscle that keeps food and acid from going up into the oesophagus.

Raft-forming anti-reflux preparations are generally used in the treatment of gastric acid-related disorders, especially GERD, heartburn and oesophagitis. ${ }^{[1]}$ Raft-forming anti-reflux preparations forms a viscous, gelatinous neutral layer or barrier on the top of the gastric acid contents. The floating barrier remains located at the lower oesophageal sphincter (LES) and prevents the acidic gastric content from getting refluxed into the oesophagus and provides symptomatic relief to GERD patients. Since this barrier floats on the surface of the stomach content like a raft on water, the barrier is called a raft and the formulations are called as "raft-forming anti-reflux preparations". The unique mechanism of action to provide relief in symptomatic GERD separates raft-forming anti-reflux preparations from traditional antacids and other therapeutic classes for treatment of GERD..$^{[1-3]}$

A raft-forming formulation requires sodium or potassium bicarbonate; in the presence of gastric acid, the bicarbonate is converted to carbon dioxide, which becomes entrapped within the gel precipitate, converting it into foam, which floats on 
the surface of the gastric contents. The antacid components contained in formulations provide a relatively $\mathrm{pH}$-neutral barrier. ${ }^{[1,4]}$ Calcium carbonate can be used as an antacid as well as a raft-strengthening agent. It releases calcium ions, which react with alginate and form an insoluble gel. ${ }^{[5,6]}$ Various polymers, especially different polysaccharides, have been used in various research works. Alginic acid, alginates and pectin are the most widely used raft-forming agents. ${ }^{[2]}$ Other polysaccharides are also being used, which include guar gum, locust bean gum, carrageenan, pectin and isapgol. ${ }^{[2,4,7]}$

All recent treatments available for GERD either have one or more problems like side effects, costly or painful. Hence the objective of the present investigation was to formulate a chewable raft-forming tablet containing an $\mathrm{H}_{2}$ antagonist (Famotidine). Famotidine blocks the action of histamine on the $\mathrm{H}_{2}$ receptors present in the stomach and thereby decreases acid secretion. ${ }^{[8]}$

\section{MATERIALS AND METHODS}

\section{Materials}

Famotidine was purchased from Yarrow Chem. (Mumbai, India). Sodium alginate was purchased from Finar Chemicals Ltd. (Ahmedabad, India). All other excipients used to prepare chewable tablets were of standard pharmaceutical grade and all chemical reagents used were of analytical grade.

\section{Methods}

\section{Preparation of raft-forming chewable tablets}

Drug, polymer and other ingredients were weighed accurately. All ingredients except the binder, volatile ingredients and lubricant were mixed thoroughly. PVP $\mathrm{K}_{30} \mathrm{M}$ was dissolved in sufficient quantity of isopropyl alcohol and added to a powder mixture to prepare a dough wet mass. The prepared wet mass was passed through a $22 \#$ sieve. The granules were allowed to dry in a hot air oven and then resifted through a $40 \#$ sieve. The granules were collected and other ingredients were added and lubricated. Tablets were compressed by a 12-mm diameter flat punch with the help of a rotary tablet compression machine.

\section{Preliminary screening}

Preliminary screening was carried out to select a good raft-forming agent, which has good raft strength. Six different raft-forming agents, viz., sodium alginate, pectin, guar gum, xanthan gum, gellan gum and isapgol were used in the study. The formulas of the different preliminary batches (batch $\mathrm{PB}_{1}-\mathrm{PB}_{6}$ ) are shown in Table 1.

\section{Optimisation by $2^{3}$ full-factorial design}

A $2^{3}$ randomised full-factorial design was used in the present investigation. In this design, three factors were evaluated, each at two levels, and experimental trials were performed at all eight possible combinations. The amount of sodium alginate, amount of calcium carbonate and amount of sodium bicarbonate were chosen as independent variables in the $2^{3}$ full-factorial design, whereas raft strength, acid neutralisation capacity and cumulative percent release at $30 \mathrm{~min}\left(\mathrm{Q}_{30}\right)$ were selected as dependent variables (responses). Different levels and their respective values are depicted in Table 2. The formulation layout of the factorial batches $\left(\mathrm{F}_{1}-\mathrm{F}_{8}\right)$ is shown in Table 3. Tablets of all the factorial batches were evaluated for weight variation, hardness, drug content, friability, raft strength, acid neutralisation capacity and in vitro drug release. The polynomial equations can be used to draw conclusions after considering the magnitude of the coefficient and the mathematical sign it carries (i.e., negative or positive). Data were analysed for regression using Microsoft Excel.

\section{Evaluation of raft-forming chewable tablets \\ General evaluation parameters for tablets}

\section{Weight variation test}

Twenty tablets were selected at random, weighed and average weight was calculated. Not more than two of the individual

\begin{tabular}{|c|c|c|c|c|c|c|}
\hline \multirow[t]{2}{*}{ Ingredients } & \multicolumn{6}{|c|}{ Quantity (mg)/tablet } \\
\hline & $\mathrm{PB}_{1}$ & $\mathrm{~PB}_{2}$ & $\mathrm{~PB}_{3}$ & $\mathrm{~PB}_{4}$ & $\mathrm{~PB}_{5}$ & $\mathrm{~PB}_{6}$ \\
\hline Famotidine & 20 & 20 & 20 & 20 & 20 & 20 \\
\hline Sodium alginate & 250 & - & - & - & - & - \\
\hline Pectin & - & 250 & - & - & - & - \\
\hline Guar gum & - & - & 250 & - & - & - \\
\hline Xanthan gum & - & - & - & 250 & - & - \\
\hline Isapgol husk & - & - & - & - & 250 & - \\
\hline Gellan gum & - & - & - & - & - & 250 \\
\hline Sodium bicarbonate & 50 & 50 & 50 & 50 & 50 & 50 \\
\hline Calcium carbonate & 150 & 150 & 150 & 150 & 150 & 150 \\
\hline $\mathrm{PVP} \mathrm{K}_{30} \mathrm{M}$ & 50 & 50 & 50 & 50 & 50 & 50 \\
\hline Mannitol & 427 & 427 & 427 & 427 & 427 & 427 \\
\hline Menthol & 3 & 3 & 3 & 3 & 3 & 3 \\
\hline Aspartame & 25 & 25 & 25 & 25 & 25 & 25 \\
\hline Flavour & q.s. & q.s. & q.s. & q.s. & q.s. & q.s. \\
\hline Talc & 10 & 10 & 10 & 10 & 10 & 10 \\
\hline Magnesium stearate & 15 & 15 & 15 & 15 & 15 & 15 \\
\hline Total weight & 1000 & 1000 & 1000 & 1000 & 1000 & 1000 \\
\hline
\end{tabular}

\begin{tabular}{lccc} 
Table 2: Coding of variables & \\
\hline Level & $\begin{array}{c}\text { Factor } \mathrm{X}_{\mathbf{1}}: \mathrm{Amt} . \\
\text { of sodium } \\
\text { alginate }(\mathbf{m g})\end{array}$ & $\begin{array}{c}\text { Factor } \mathrm{X}_{2}: \text { Amt. } \\
\text { of calcium } \\
\text { carbonate }(\mathbf{m g})\end{array}$ & $\begin{array}{c}\text { Factor } \mathrm{X}_{3}: \text { Amt. } \\
\text { of sodium } \\
\text { bicarbonate }(\mathbf{m g})\end{array}$ \\
\hline-1 & 250 & 150 & 25 \\
+1 & 350 & 210 & 50 \\
\hline
\end{tabular}

Mannitol was added up to $1000 \mathrm{mg}$ and all other excipients were added as shown in Table 2

\begin{tabular}{|c|c|c|c|}
\hline Batch & $x_{1}$ & $x_{2}$ & $X_{3}$ \\
\hline$F_{1}$ & -1 & -1 & -1 \\
\hline $\mathrm{F}_{2}^{1}$ & +1 & -1 & -1 \\
\hline $\mathrm{F}_{3}^{2}$ & -1 & +1 & -1 \\
\hline $\mathrm{F}_{4}^{3}$ & -1 & -1 & +1 \\
\hline $\mathrm{F}_{5}^{4}$ & +1 & +1 & -1 \\
\hline $\mathrm{F}_{6}^{5}$ & +1 & -1 & +1 \\
\hline $\mathrm{F}_{7}^{6}$ & -1 & +1 & +1 \\
\hline $\mathrm{F}_{8}^{\prime}$ & +1 & +1 & +1 \\
\hline
\end{tabular}


weights should deviate from the average weight by more than $10 \%$.

\section{Friability}

For each formulation, a pre-weighed tablet sample (six tablets) was placed in a Roche friabilator (Electrolab, Mumbai, India), which is then operated for 100 revolutions. The tablets were de-dusted and reweighed. Conventional compressed tablets that lose $<0.5$ to $1 \%$ of their weight are considered acceptable.

\section{Hardness}

Hardness of tablets was determined using a Pfizer hardness tester (Campbell Electronics, Mumbai, India).

\section{Content uniformity}

Twenty tablets were weighed and powdered in a glass mortar. A quantity of powder equivalent to $20 \mathrm{mg}$ of Famotidine was accurately weighed and transferred into a $10 \mathrm{ml}$ volumetric flask. Dimethyl formamide was added up to $10 \mathrm{ml}$ and shaken well. The solution was filtered and $1 \mathrm{ml}$ of the above solution was transferred into a $100 \mathrm{ml}$ volumetric flask. A solution of $0.1 \mathrm{~N} \mathrm{HCl}$ was added and the final volume in the flask was adjusted up to $100 \mathrm{ml}$. Absorbance of the resulting solution was measured at a $\lambda_{\max }$ of $265 \mathrm{~nm}$ using UV-Visible spectrophotometer and the amount of the Famotidine was calculated by using the calibration curve method.

\section{Raft strength measurement by in-house method}

A tablet powder equivalent to unit dose was transferred to $150 \mathrm{ml}$ of $0.1 \mathrm{~N} \mathrm{HCl}$ and maintained at $37^{\circ} \mathrm{C}$ in a $250 \mathrm{ml}$ glass beaker. Each raft was allowed to form around an L-shaped wire probe (diameter: $1.2 \mathrm{~mm}$ ) held upright in the beaker throughout the whole period (30 min) of raft development. ${ }^{[9]}$ Raft strength was estimated using the modified balance method. Water was added dropwise to the pan and the weight of water required to break the raft was recorded.

Note: A double-pan dispensing balance was modified for raft strength measurement. One pan of the dispensing balance was replaced with an L-shaped wire probe as shown in Figure 1.

\section{Acid neutralisation capacity}

A tablet powder equivalent to unit dose was transferred to a $250 \mathrm{ml}$ beaker; $50 \mathrm{ml}$ of water was added to it and was mixed on a magnetic stirrer for $1 \mathrm{~min}$. A $30-\mathrm{ml}$ volume of $1.0 \mathrm{~N} \mathrm{HCl}$ was

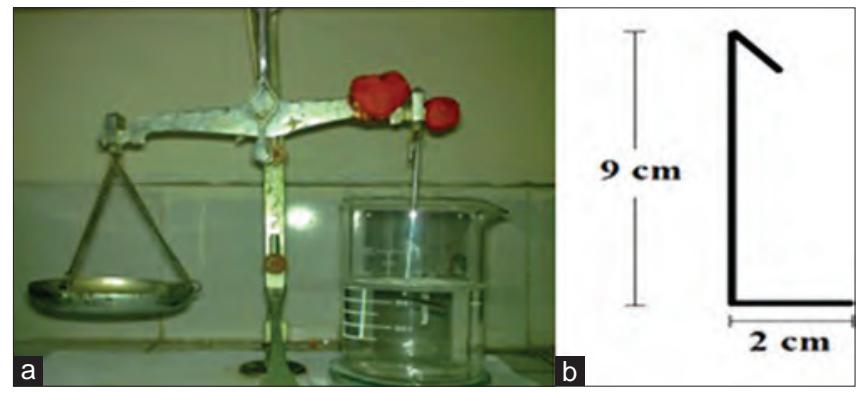

Figure 1: (a) Modified balance method. (b) Wire probe for raft strength measurement added with continued stirring on the magnetic stirrer for $10 \mathrm{~min}$ after addition of the acid. Stirring was discontinued briefly and the gum base was removed using a long needle without delay. The needle was promptly rinsed with $20 \mathrm{ml}$ of water, and the washing was collected in the beaker; stirring was resumed for 5 min. Titration was begun immediately. Excess $\mathrm{HCl}$ was titrated against $0.5 \mathrm{~N}$ sodium hydroxide to attain a stable $\mathrm{pH}$ of 3.5. The number of $\mathrm{mEq}$ of acid consumed by the tablet tested was calculated by the following formula: ${ }^{[10]}$

$$
\text { Total } \mathrm{mEq}=(30 \times \mathrm{N} \mathrm{HCl})-(\mathrm{V} \mathrm{NaOH} \times \mathrm{N} \mathrm{NaOH})
$$

Where, $\mathrm{N} \mathrm{HCI}=$ Normality of $\mathrm{HCl} ; \mathrm{V} \mathrm{NaOH}=$ Volume of $\mathrm{NaOH}$ required; and $\mathrm{N} \mathrm{NaOH}=$ Normality of $\mathrm{NaOH}$.

\section{In vitro drug release study}

In vitro drug release study of Famotidine chewable tablets $(n=3)$ was performed using USP (United States Pharmacopoeia) apparatus II (TDT-08T; Electrolab) fitted with a paddle (50 r.p.m.) at $37 \pm 0.5^{\circ} \mathrm{C}$ using a simulated gastric fluid $(\mathrm{pH} 1.2 ; 900 \mathrm{ml})$ as a dissolution medium. The tablet was powdered and then added to the dissolution medium. At pre-determined time intervals, 10 -ml samples were withdrawn, filtered through a $0.45-\mu \mathrm{m}$ membrane filter and analysed at $265 \mathrm{~nm}$ using a Shimadzu UV 1800 double-beam spectrophotometer (Shimadzu, Kyoto, Japan). Cumulative percentage drug release was calculated using an equation obtained from a calibration curve, which was developed in the range $5-25 \mu \mathrm{g} / \mathrm{ml}$ for $0.1 \mathrm{~N} \mathrm{HCl}$.

\section{Raft strength measurement by Texture Analyzer}

The raft strength of the most satisfactory formulation (batch $\mathrm{F}_{5}$ ) was determined by a sophisticated instrument called Texture Analyzer (Brookfield QTS).

Powder of tablets equivalent to unit dose was transferred to $150 \mathrm{ml}$ of $0.1 \mathrm{~N} \mathrm{HCl}$ and maintained at $37^{\circ} \mathrm{C}$ in a $250 \mathrm{ml}$ glass beaker. The raft was allowed to form around an L-shaped wire probe (diameter: $1 \mathrm{~mm}$ ) held upright in the beaker throughout the whole period $(30 \mathrm{~min})$ of raft development. After $30 \mathrm{~min}$ of raft development, the probe was pulled vertically up through the raft at a rate of $30 \mathrm{~mm} / \mathrm{min}$. The force required to pull the wire probe up through the raft was recorded by the Texture Analyzer. ${ }^{[9]}$

\section{Drug-excipient compatibility study}

\section{Fourier transform infrared spectrophotometry}

A drug-excipient interaction plays a vital role in the release of drug from the formulation. Fourier transform infrared (FTIR) spectroscopy has been used to study the physical and chemical interactions between drugs and excipients. The FTIR spectra of Famotidine and a mixture of Famotidine with major excipients were recorded using the $\mathrm{KBr}$ mixing method using an FTIR instrument (FTIR-8400S; Shimadzu).

\section{Differential scanning calorimetry study}

Differential scanning calorimetry (DSC) study was carried out using the Shimadzu DSC-60 (Shimadzu) instrument to check 
drug-excipient compatibility. The DSC thermograms of the pure drug Famotidine and of the physical mixtures of Famotidine with excipients were obtained. DSC aluminium cells were used as a sample holder and a blank DSC aluminium cell was used as reference. A 2- to 3-mg weight of sample was used for analysis. Thermograms were recorded over the range $50-300^{\circ} \mathrm{C}$.

\section{Stability studies of the optimised formulation}

Stability testing of drug products begins as a part of drug discovery and ends with the demise of the compound or commercial product. To assess drug and formulation stability, short-term stability studies were done for 1 month. The stability studies were carried out on the most satisfactory formulations (batch $\mathrm{F}_{5}$ ). The most satisfactory formulations were sealed in aluminium packaging and kept in a humid chamber maintained at $40 \pm 2^{\circ} \mathrm{C} / 75 \pm 5 \%$ relative humidity $(\mathrm{RH})$ for 1 month. The optimised formulation sealed in aluminium foil was also kept at room temperature and humid condition. At the end of the storage time, the samples were analysed for raft strength, in vitro drug release and $\%$ drug content.

The in vitro drug release profiles for both formulations (initial and after storage at $40 \pm 2{ }^{\circ} \mathrm{C} / 75 \pm 5 \% \mathrm{RH}$ for 1 month) were compared by the similarity factor $\left(f_{2}\right)$.

\section{RESULTS AND DISCUSSION}

\section{Results of preliminary screening}

Tablets prepared using different raft-forming agents were tested for raft strength in $0.1 \mathrm{~N} \mathrm{HCl}$.

Among all six batches prepared with six different raft-forming agents, tablets prepared using sodium alginate (batch $B_{1}$ ) had maximum raft strength. So sodium alginate was selected as the

\begin{tabular}{llc}
$\begin{array}{l}\text { Table 4: Raft strength of preliminary batches } \\
\mathrm{PB}_{1}-\mathrm{PB}_{6}\end{array}$ & \\
\hline Batch & Raft-forming agent & $\begin{array}{c}\text { Raft } \\
\text { strength (g) }\end{array}$ \\
\hline $\mathrm{PB}_{1}$ & Sodium alginate & $4.5 \pm 0.25$ \\
$\mathrm{~PB}_{2}$ & Pectin & $2.2 \pm 0.26$ \\
$\mathrm{~PB}_{3}$ & Guar gum & $1.2 \pm 0.10$ \\
$\mathrm{~PB}_{4}$ & Xanthan gum & $1.0 \pm 0.15$ \\
$\mathrm{~PB}_{5}$ & Isapgol husk & $1.0 \pm 0.20$ \\
$\mathrm{~PB}_{6}$ & Gellan gum & $0.9 \pm 0.15$ \\
\hline
\end{tabular}

All values are mean $\pm \mathrm{SD}(n=3)$ raft-forming agent for further studies. All results are shown in Table 4.

\section{Results of $2^{3}$ full-factorial design}

All results for physicochemical parameters like hardness, weight variation, thickness, $\%$ drug content and friability are shown in Table 5. All results were found to be satisfactory and within a normal range. The raft strength and acid neutralisation capacity of all factorial batches are shown in Table 6. Batch $\mathrm{F}_{5}$ was found to have maximum raft strength of $6.5 \mathrm{~g}$. All batches had acid neutralisation capacity in the range of $6.7 \pm 0.17$ to $9.2 \pm 0.15$, which was as per the limits described in USP 28. It was concluded that the amount of calcium carbonate critical for raft strength (cross-linking with sodium alginate) and the amount sodium bicarbonate critical for floating (porous structure formation) of raft and neutralisation. High level of calcium carbonate and low level of sodium bicarbonate showed better raft strength and neutralisation capacity [Table 6]. In vitro drug release study showed that more than $80 \%$ of the drug was released in $30 \mathrm{~min}$ and the entire drug was released within $60 \mathrm{~min}$ in all factorial batches. The in vitro drug release profiles of all factorial batches are shown in Figure 2. All parameters were found to be satisfactory for all factorial batches, so the batch with maximum raft strength, that is batch $\mathrm{F}_{5}$, was selected as the optimised batch. Table 7 shows a summary of the regression analysis of the factorial design batches. $R^{2}$-value for raft strength $(\mathrm{g})$ and acid neutralisation capacity was 0.9997 and 0.9951 , respectively, indicating good correlation between the dependent and independent variables. The reduced models were developed for response variables by omitting insignificant terms with $P>0.05$.

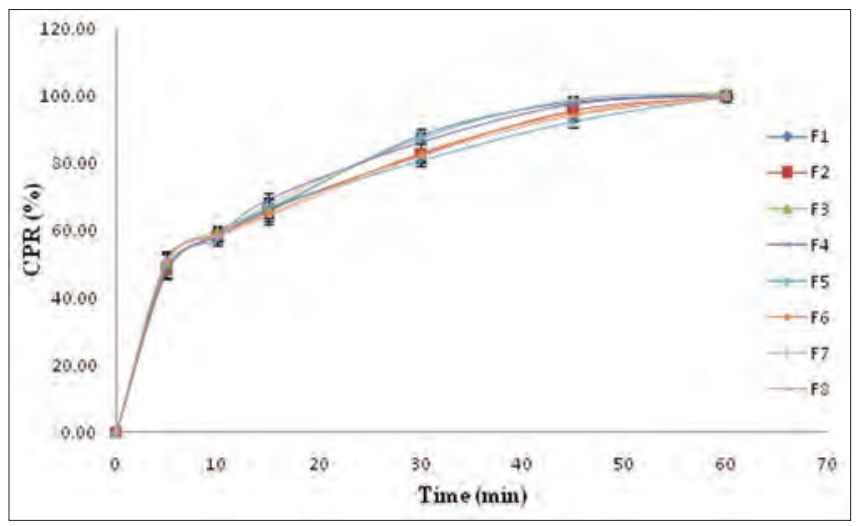

Figure 2: In vitro drug release profile of factorial batches

\begin{tabular}{|c|c|c|c|c|c|}
\hline Batch code & Weight variation* $(\mathrm{mg})$ & Hardness $\left(\mathrm{kg} / \mathrm{cm}^{2}\right)$ & Thickness (mm) & $\%$ Drug content & Friability\# (\%) \\
\hline $\mathrm{F}_{1}$ & $992.39 \pm 2.38$ & $5.47 \pm 0.15$ & $5.91 \pm 0.025$ & $99.78 \pm 0.59$ & 0.67 \\
\hline $\mathrm{F}_{2}$ & $990.71 \pm 2.98$ & $6.20 \pm 0.26$ & $5.83 \pm 0.032$ & $99.33 \pm 1.04$ & 0.57 \\
\hline $\mathrm{F}_{3}$ & $992.6 \pm 2.86$ & $5.23 \pm 0.12$ & $5.95 \pm 0.031$ & $99.44 \pm 1.27$ & 0.94 \\
\hline $\mathrm{F}_{4}$ & $991.37 \pm 2.07$ & $5.40 \pm 0.17$ & $5.89 \pm 0.070$ & $100.17 \pm 0.93$ & 0.70 \\
\hline $\mathrm{F}_{5}$ & $991.41 \pm 3.89$ & $5.97 \pm 0.25$ & $5.88 \pm 0.045$ & $99.39 \pm 0.63$ & 0.68 \\
\hline $\mathrm{F}_{6}$ & $993.21 \pm 1.97$ & $6.17 \pm 0.15$ & $5.90 \pm 0.036$ & $99.50 \pm 0.73$ & 0.40 \\
\hline $\mathrm{F}_{7}$ & $992.81 \pm 3.02$ & $5.13 \pm 0.21$ & $5.84 \pm 0.062$ & $98.44 \pm 0.67$ & 0.96 \\
\hline $\mathrm{F}_{8}^{\prime}$ & $993.62 \pm 2.42$ & $5.60 \pm 0.10$ & $5.90 \pm 0.035$ & $100.72 \pm 0.95$ & 0.69 \\
\hline
\end{tabular}


Terms with $P<0.05$ were considered statistically significance and retained in the reduced model.

Results of raft strength measurement by Texture Analyzer

The raft strength of the optimised formulation (batch $\mathrm{F}_{5}$ ) was measured by the Texture Analyzer. The graph of load vs. time is shown in Figure 3. Initially load was increased with time, maximum load was shown when the raft was broken and then it decreased sharply. The maximum raft strength observed at the breaking (rupture) point of the raft was found to be $5.0 \mathrm{~g}$.

\section{Results of fourier transform infrared spectrophotometry} The IR spectra of pure drug Famotidine and of the physical

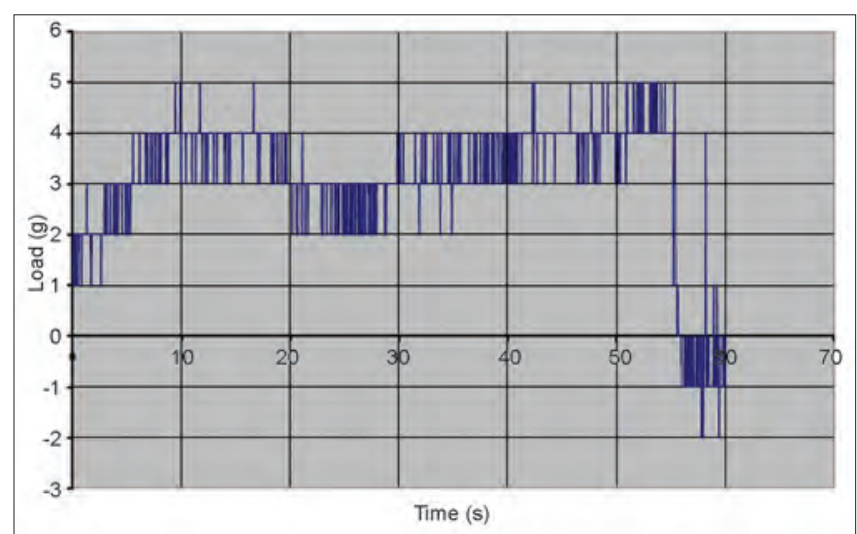

Figure 3: Graph of load vs. time for batch $\mathrm{F}_{5}$
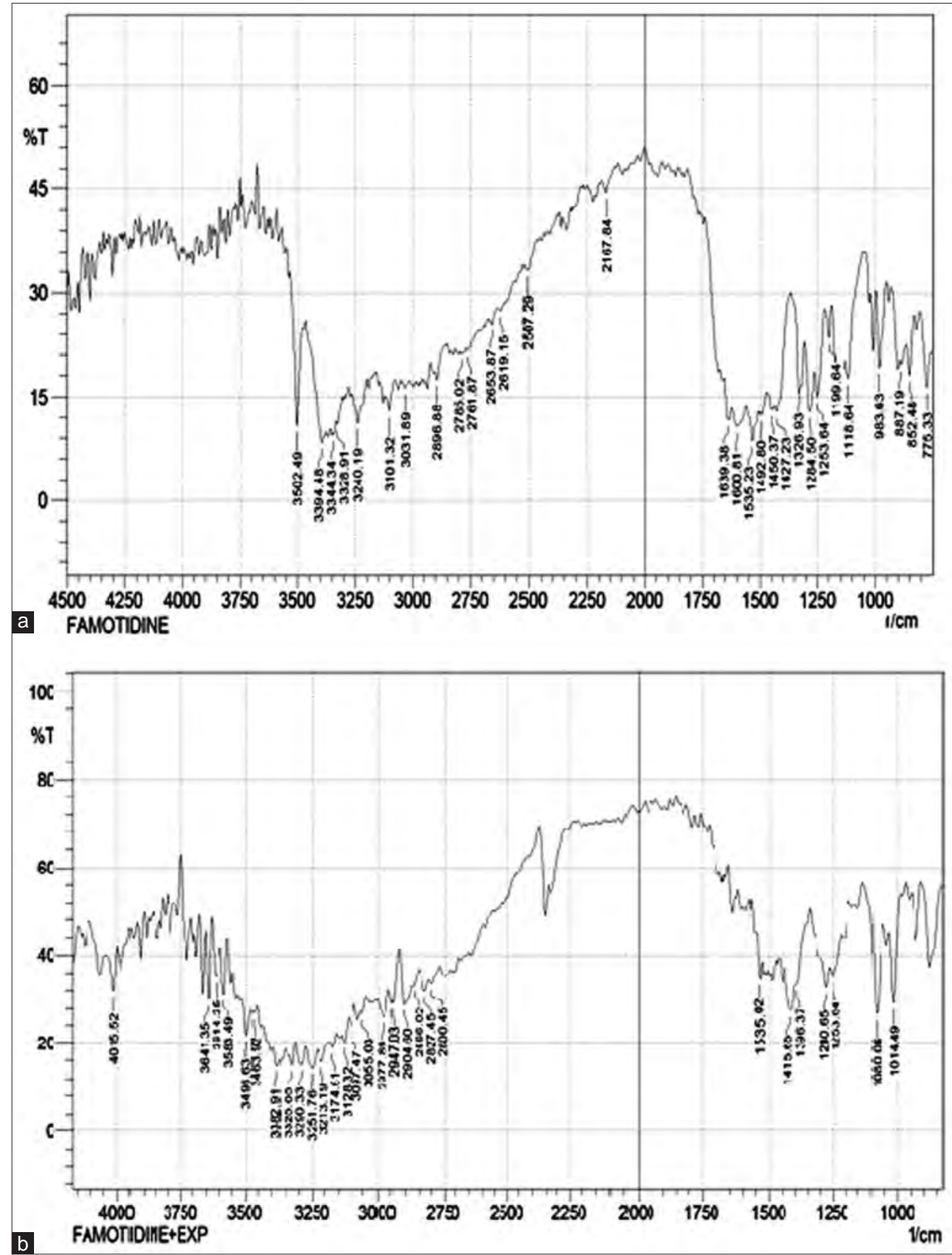

Figure 4: Fourier transform infrared spectra of Famotidine (a) and Famotidine with excipients (b) 
mixtures of the drug with excipients are as shown in Figure 4. Pure drug Famotidine exhibited various peaks due to the presence of specific functional groups. Peaks of the major functional groups of the drug were obtained at 1284.50, 1535.23, 3101.32 and 3394.48. It was observed that the same peaks of drug functional groups were present in the IR spectra of the drug-excipients mixture and other peaks of excipients were present. Hence it was concluded that no interaction was found between the drug and excipients.

\section{Results of DSC study}

DSC thermograms were obtained for pure Famotidine and chewable tablet containing Famotidine and other excipients. Pure powdered Famotidine showed a melting endotherm at $169.23^{\circ} \mathrm{C}$. The DSC thermogram of chewable tablet showed a melting peak of the drug at $171.21^{\circ} \mathrm{C}$. There was no significant difference in melting point of drug in both samples. It indicated that the drug was present in its characteristic physical and chemical form. It was compatible with all excipients present in the tablet and there was no major interaction of drug with excipients. The DSC thermograms of drug and of the mixture of drug and excipients are shown in Figure 5.

\section{Results of stability studies}

The optimised formulation (batch $\mathrm{F}_{5}$ ) stored at $40 \pm 2{ }^{\circ} \mathrm{C} / 75 \pm 5 \%$ was found stable. After storage at $40 \pm 2{ }^{\circ} \mathrm{C} / 75 \pm 5 \%$, cumulative percentage drug release, raft strength, acid neutralisation capacity and $\%$ drug content were nearly similar to the initial results. So, it was clear that the drug and the formulation were thermally stable as well as not affected by the high humidity at $40 \pm 2{ }^{\circ} \mathrm{C} / 75 \pm 5 \%$. The similarity factor of the batch after the stability study was

\section{Table 6: Raft strength and acid neutralisation capacity of factorial batches}

\begin{tabular}{lcc}
\hline Batch & Raft strength $(\mathbf{g})$ & Acid neutralisation capacity $(\mathrm{mEq})$ \\
\hline $\mathrm{F}_{1}$ & $5.3 \pm 0.15$ & $6.7 \pm 0.17$ \\
$\mathrm{~F}_{2}$ & $5.8 \pm 0.10$ & $6.8 \pm 0.10$ \\
$\mathrm{~F}_{3}$ & $4.5 \pm 0.21$ & $8.6 \pm 0.06$ \\
$\mathrm{~F}_{4}$ & $4.9 \pm 0.15$ & $7.3 \pm 0.21$ \\
$\mathrm{~F}_{5}$ & $6.5 \pm 0.15$ & $8.8 \pm 0.12$ \\
$\mathrm{~F}_{6}$ & $5.3 \pm 0.21$ & $7.6 \pm 0.25$ \\
$\mathrm{~F}_{7}$ & $4.3 \pm 0.06$ & $9.1 \pm 0.21$ \\
$\mathrm{~F}_{8}$ & $6.2 \pm 0.06$ & $9.2 \pm 0.15$ \\
\hline \multicolumn{2}{l}{ All values are mean $\pm \mathrm{SD}(n=3)$} &
\end{tabular}

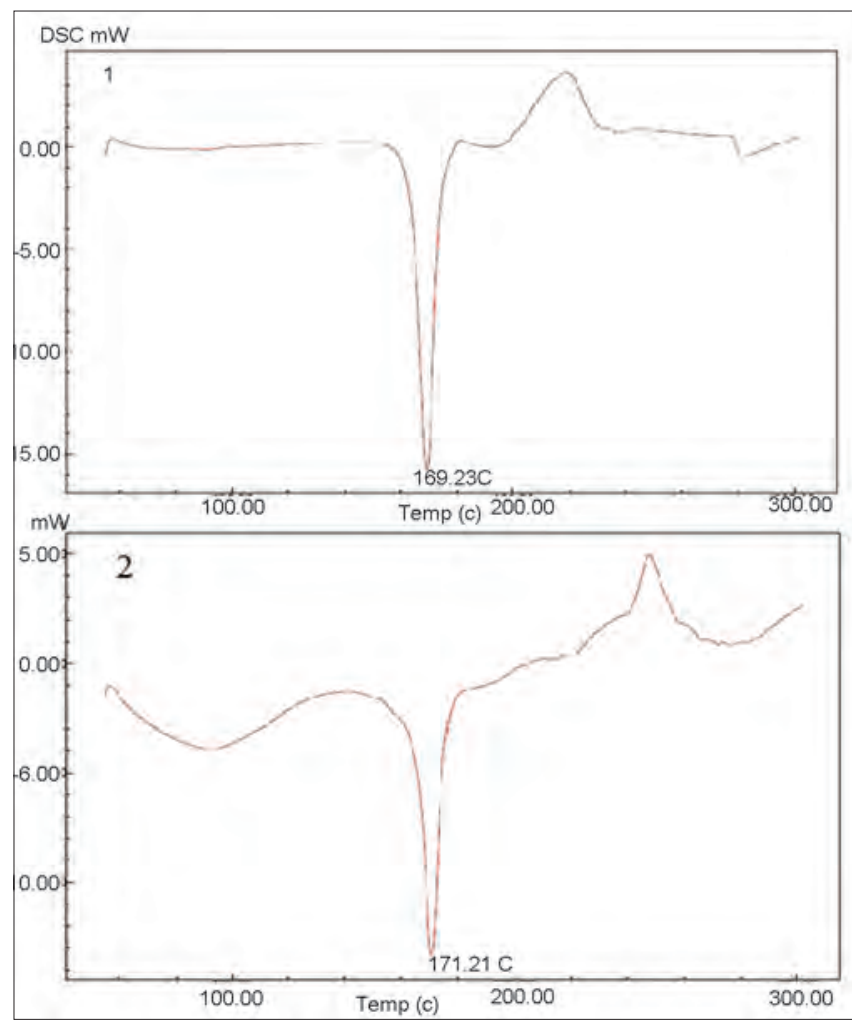

Figure 5: Differential scanning calorimetry thermograms of Famotidine and Famotidine chewable tablet

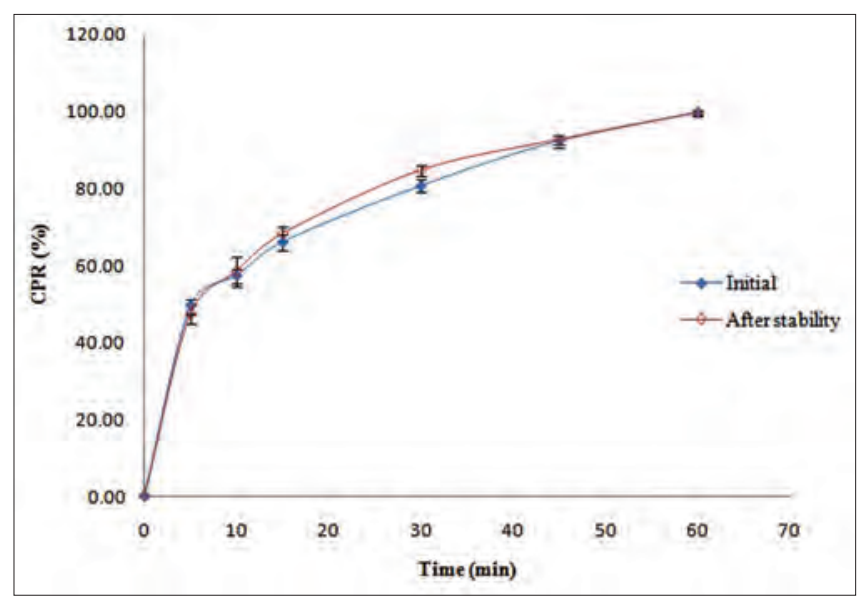

Figure 6: In vitro drug release profile of batch $F_{5}$ after stability study and comparison with initial

Table 7: Summary of results of regression analysis of factorial design batches

\begin{tabular}{|c|c|c|c|c|c|c|c|}
\hline \multirow[b]{2}{*}{ Response (raft strength) } & \multicolumn{7}{|c|}{ For raft strength } \\
\hline & $\mathbf{b}_{0}$ & $b_{1}$ & $b_{2}$ & $b_{3}$ & $b_{12}$ & $b_{23}$ & $b_{13}$ \\
\hline$P$ value & 0.001 & 0.013 & 0.204 & 0.040 & 0.021 & 0.144 & 0.257 \\
\hline FM & 5.35 & 0.59 & 0.04 & -0.20 & 0.37 & 0.05 & -0.03 \\
\hline \multirow[t]{2}{*}{ RM } & 5.35 & 0.59 & - & -0.20 & 0.37 & - & - \\
\hline & \multicolumn{7}{|c|}{ For ANC } \\
\hline Response (ANC) & $\mathbf{b}_{0}$ & $b_{1}$ & $b_{2}$ & $b_{3}$ & $\mathbf{b}_{12}$ & $b_{23}$ & b13 \\
\hline$P$ value & 0.001 & 0.125 & 0.009 & 0.0261 & 0.344 & 0.169 & 0.344 \\
\hline FM & 7.98 & 0.06 & 0.88 & 0.30 & -0.02 & -0.046 & 0.02 \\
\hline RM & 7.98 & - & 0.88 & 0.30 & - & - & - \\
\hline
\end{tabular}


found to be 79.61 when compared with the initial drug release profile. The comparative dissolution profile of batch $\mathrm{F}_{5}$ before and after stability study is shown in Figure 6.

\section{CONCLUSION}

It was concluded that chewable tablet prepared by sodium alginate (raft-forming agent) in combination with calcium carbonate (antacid) and sodium bicarbonate (gas generating agent) can form a floating raft in the presence of $0.1 \mathrm{~N} \mathrm{HCl}$. Raft strength was directly proportional to the amount of sodium alginate in the tablet. The amount of calcium carbonate and amount of sodium bicarbonate in the tablet were critical parameters in the formulation development. The optimised formulation had good raft strength, sufficient acid neutralisation capacity and satisfactory in vitro drug release. The drug was also compatible with all excipients used in the formulation. The formulation was also stable at accelerated conditions of temperature and humidity.

\section{REFERENCES}

1. Mandel KG, Daggy BP, Jacoby HI, Brodie DA. Review article: Alginate raft formulations in the treatment of heartburn and acid reflux. Aliment Pharmacol Ther 2000;14:669-90.

2. Kapadia CJ, Mane VB. Raft forming agents: Antireflux formulation. Drug Dev Ind Pharm 2007;33:1350-61.

3. Washington N, Wilson CG, Greaves JL, Danneskiold Samsoe P.
An investigation into the floating behaviour of a pectin-containing anti-reflux formulation by means of gamma scintigraphy. Scand J Gastroenterol 1988;23:920-4.

4. Waterhouse ET, Washington C, Washington N. An investigation into efficacy of pectin based anti-reflux formulation-Aflurax. Int J Pharm 2000;209:79-85.

5. Hampson FC, Jolliffe IG, Bakhtyari A, Taylor G, Sykes J, Johnstone LM, et al. Alginate-antacid combinations: Raft formation and gastric retention studies. Drug Dev Ind Pharm 2010;36:614-23.

6. Johnson FA, Craig DQ, Mercer AD, Chauhan S. The effects of alginate molecular structure and formulation variables on the physical characteristics of alginate raft systems. Int J Pharm 1997;159:35-42.

7. Mandelkar SV, Marathe SS, Devrajan PV. A novel raft-forming suspension using a natural dietary fibre. Int $\mathrm{J}$ Pharm 1997;148:117-21.

8. Tripathi KD. Drugs for peptic ulcer. In: Tripathi M, editor. Essential of Medicinal Pharmacology. New Delhi: Jaypee Brothers Medical Publisher; 2008. p. 627-51.

9. Hampson FC, Ferndale A, Strugala V, Sykes J, Jolliffe IG, Dettmar PW. Alginate rafts and their characterization. Int $J$ Pharm 2005;294:137-47.

10. United States Pharmacopoeia 28, National Formulary 23, Twinbrook Parkway, Rockville, MD: United States Pharmacopeial Convention, Inc; 2005, p. 2304.

How to cite this article: Prajapati ST, Mehta AP, Modhia IP, Patel $\mathrm{CN}$. Formulation and optimisation of raft-forming chewable tablets containing $\mathrm{H} 2$ antagonist. Int J Pharma Investig 2012;2:176-82. Source of Support: Nil. Conflict of Interest: None declared.

\section{New features on the journal's website}

Optimized content for mobile and hand-held devices

HTML pages have been optimized of mobile and other hand-held devices (such as iPad, Kindle, iPod) for faster browsing speed.

Click on [Mobile Full text] from Table of Contents page.

This is simple HTML version for faster download on mobiles (if viewed on desktop, it will be automatically redirected to full HTML version)

\section{E-Pub for hand-held devices}

EPUB is an open e-book standard recommended by The International Digital Publishing Forum which is designed for reflowable content i.e. the text display can be optimized for a particular display device.

Click on [EPub] from Table of Contents page.

There are various e-Pub readers such as for Windows: Digital Editions, OS X: Calibre/Bookworm, iPhone/iPod Touch/iPad: Stanza, and Linux: Calibre/Bookworm.

\section{E-Book for desktop}

One can also see the entire issue as printed here in a 'flip book' version on desktops.

Links are available from Current Issue as well as Archives pages.

Click on View as eBook 